\title{
Water Management and Soil Fertility Status at A Reclaimed Tidal Lowland of Telang Jaya Village, South Sumatra, Indonesia
}

\author{
BAKRI $^{1}$, MOMON SODIK IMANUDIN $^{1 *}$ AND WAHYU L.CANDRA ${ }^{2}$ \\ ${ }^{1}$ Department of Soil Science Faculty of Agriculture, Sriwijaya University, Indonesia \\ ${ }^{2}$ Researcher at Lowland and Coastal Data Information Center of South Sumatra, Indonesia
}

\begin{abstract}
Tidal lowland reclamation area has a great prospect due to its vast area to support the improvement of national food security and the development of agribusiness system. Based on these potentials, it is necessary to study water management the physical dan chemical characteristics of soil on tidal land at Telang Jaya, South Sumatra. The aim of the study is to develop micro water management in the field level for rice cultivation, and to evaluate the soil fertility in relation to the rice production. The soil properties can be used to determine the level of soil fertility and the land management problem at the area. Research method was done by experimental research in combination with survey and monitoring. To develop field operation model, the ground water table fluctuation was record in daily bases at rice field. Soil samples were taken from 0-20 cm depth (the root depth for common food crops) and then analyzed in the laboratory. The result had showed that the soil fertility status at Telang Jaya was low to moderate. The limiting factors of soil fertility found in this study were consisted of low nitrogent content, low $\mathrm{C}$-organic content and acid soil condition (low bases ions and $\mathrm{pH}$ ). Ground water taken from February to March was maintained on 10 to $(-10) \mathrm{cm}$ related to the soil surface. It was sufficient for crop water requirement. Water management objective for second rice was mainly for control drainage during the intial stage, and retain rainfall water. Pumping irrigation was required during Elnina climatic condition at generative phase of rice. By proper water management system rice production could achive 5 ton/ha.
\end{abstract}

Keywords: Tidal low land, water management, soil fertility

\section{INTRODUCTION}

Reclamation or development of tidal lowland area at South Sumatra had been conducted by the government since 1969 through transmigration program. Development of tidal lowland reclamation is an activity with

\footnotetext{
Correspondence: Momon Sodik Imanudin;

Department of Soil Science, Faculty of Agriculture,

Sriwijaya University, Indonesia; Email: momon_unsri@yahoo.co.id.
}

objectives to improve function and advantage of this land area as potential natural resource for the benefit and welfare of the community (Schultz et al., 2015). The total area that has been reclaimed in South Sumatera until 2004 is 373.000 ha. (PIRA South Sumatra, 2004).

The key success for tidal lowland agriculture is how the farmer could capable to maintenance the water table in farm level. The 
water status was mainly depending on the hydrotofography class, rain water, tide fluctuation, and drainage facility. Development of tidal lowland area for agricultural enterprise is closely related to management of soil quality an water network to support agricultural system (Ngudiantoro, 2010). Reported by Bakri et al. (2015) Utilization of tidal lowland for two time rice and once corn could prevent changed in land use. water drainage system should be maintained, so that the land continues to be productive for food crops. Changes in land use are often caused by poor drainage which results in decreased productivity.

Area of reclaimed tidal lowland is classified into four hydrotopographical classes consisting of A, B, C and D types. Each area has different land resource characteristics, especially in term of soil, climate and hydrology conditions. Tidal lowland area is different than irrigated land or dry land that are commonly known by the community. The differences are related to soil fertility, available water resource and its management. This tidal lowland has vast area and is utilized for agricultural enterprise (Supriadi, 2005).

The land use implementation should take into account soil water condition so that its function and role can be sustained in term of economical and ecological aspects. The problems face in agricultural development at tidal lowland area are consisted of water regime fluctuation, variable nature of soil physical and chemical characteristics, high acidity, toxic element, salt water intrusion and low natural fertility of soil.

Soil fertility is soil ability to provide nutrients, water and oxygen in balance condition for crops. The soil capability is affected by its physical, chemical and biological characteristics. In tidal lowland generally found the nutrient status is low. Particularly of macro nutrient Nitrogen, Phosphate and potassium. That is due to acidic soil (low $\mathrm{pH}$ ) was cause the increasing solubility of Aluminum, Iron, and manganese. These elements are harmful for crop and can absorb macro nutrient through Al-P bonds (Imanudin et al., 2018). Added by Fahmi et al. (2018) that the dynamics of soil $\mathrm{pH}$, nutrient status in root zone of tidal lowland are highly dependent on the pattern of water inundation and tidal water dynamics. In addition also effected by $\mathrm{Fe}$ and $\mathrm{Al}$ content in the soil. Therefore to improve the soil fertility at any different typology class was required different input.

Land characteristics at Talang Jaya Village can be classified as $\mathrm{C}$ land typhology which is characterized by existence of acid sulphate layer. The main purpose for water management in that area is to retain rain water and control drainage in the tertiary canal (Hartoyo et al., 2010). Natural condition of phyrite layer was located below water table depth during wet season, whereas water table depth is drop below phyrite layer during dry season on land with $\mathrm{C}$ flooding type at tidal lowland area. Oxidation process will occur if water table depth is drop below phyrite layer. This process is harmful because it will produce sulphate acid folowed by iron and aluminum solubility which have adverse effect for crops (Imanudin et al., 2011). The condition of water table dynamics toward phyrite layer depth is the key factor in constructing water management strategy and 
planting pattern determination at each development unit of tidal lowland area (Megawaty et al., 2012).

According to Imanudin et al. (2011), soil $\mathrm{pH}$ at $\mathrm{C}$ typhology land area during dry season is very low and water table depth will progressively increase with the arrival of the rainy season so that soil $\mathrm{pH}$ will also increase. Tidal lowland development requires proper planning, management and utilization as well as application of appropriate technology, especially soil and water management. Control of water table elevation at tidal lowland area is the key process that should be properly implemented through water management at macro and micro levels.

The objective of this paper is to study water management for rice cultivation in the micro level (tertiary block), and to evaluate the physical and chemical conditions of soil at Talang Jaya Village, South Sumatra in order to determine soil fertility condition and problems related to soil management at this area.

\section{MATERIALS AND METHODS}

This study was conducted at tidal lowland reclamation area in Telang Jaya Village. It is located at Muara Telang Subdistrict, of Banyuasin District at elevation of $30 \mathrm{~cm}$ above sea water (Figure 1). This study site is classified as tidal lowland area with Ctyphology. Most of community members in Telang Jaya Village have livelihood as farmers. Agricultural enterprise conducted by community members or farmers is rice cultivation. Agricultural enterprise at Telang Jaya Village is consisted of two times planting per year, that is rice as food crops during the first planting season (MT1) and second planting season (MT2). First season is on November to February (MT1) and the second (MT2) is planted on March to May. This study was carried out in the second period of rice cultivation (MT2).

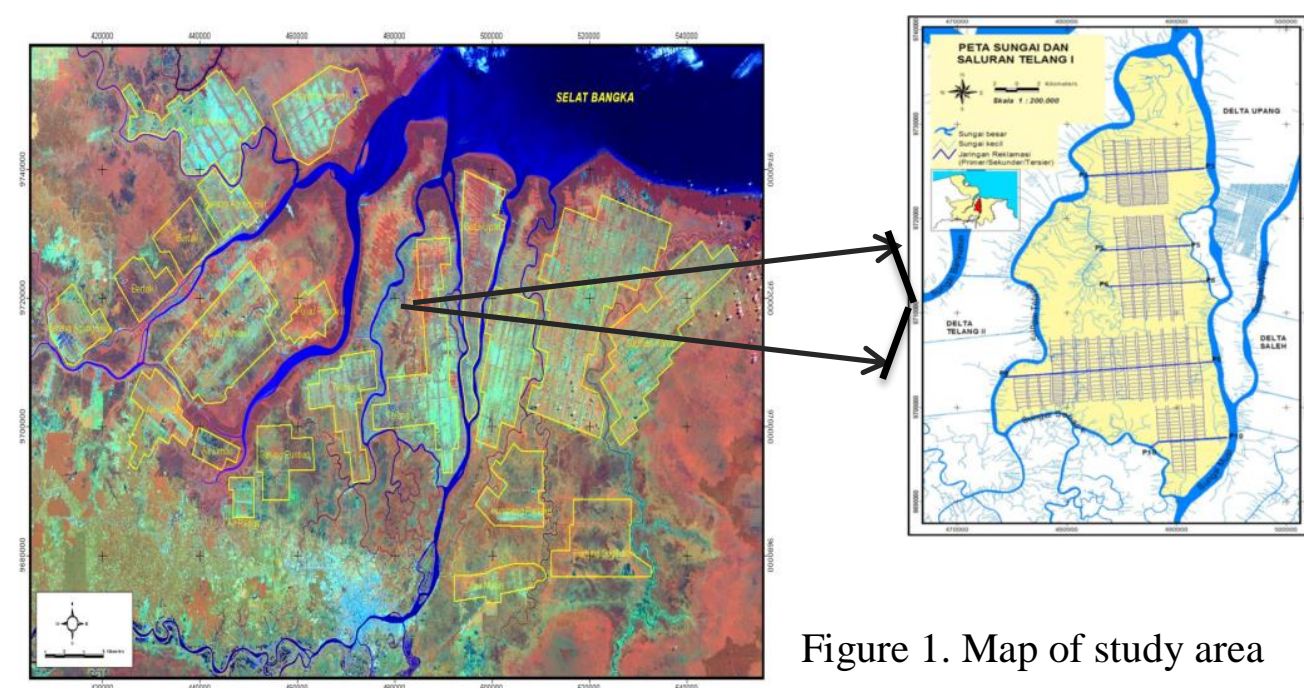

Journal of Wetlands Environmental Management 
Soil analysis was done at Soil and Water Conservation and Soil Physics Laboratory, Soil Science Department, Faculty of Agriculture, Sriwijaya University, Inderalaya. The research was conducted from November to February 2017.

The research activities were consisted of field work and laboratory work. The method used for field survey activity was survey method using detail scale. Survey activity was done to study the condition of soil water table dynamics in order to determine the proper water management system. In order to determine how far land receive water excess from the system, then analysis of cummulative daily water table toward plant's tolerance limit to water table elevation was implemented Data collecting of water table was done in three point (10 m (Well 1); $50 \mathrm{~m}$ (Well 2); $100 \mathrm{~m}$ (Well 3) of tertiary canal) to determine water management condition, channel condition and land condition. To identify the nutrient status, three soil samples were taken at depth of $0-20 \mathrm{~cm}$ at $10 \mathrm{~m}$ (TS1), $50 \mathrm{~m}$ (TS2), or $100 \mathrm{~m}$ (TS3) from tertiary canal.

Two types of data used in this study were primary and secondary data. Primary data was obtained from field observation and measurement results, whereas secondary data was obtained from several govenrment agencies and other institutions which actively involved in development of tidal lowland area.

Field data required in this study was climate, hydrology and water network system including channel condition, condition of water control infrastructure, water table depth at tertiary blocks, water elevation in secondary and tertiary channels, seawater tidal condition, rainfall, temperature, planting pattern and land use scheme. The oberved parameters were consisted of soil texture, soil $\mathrm{pH}, \mathrm{N}, \mathrm{P}$, and $\mathrm{K}$ contents, C-organic, $\mathrm{Al}$ and $\mathrm{Fe}$.

Proper water management was to find out in this study. Micro water management in tertiary block was done by tertiary gate operation. The water management objective is control drainage option during early season and retention in vegetative to generative phase.

\section{RESULTS AND DISCUSSION}

\section{General condition of the area study}

Most of land at Telang Jaya Village can be categorized as C-type land so that the tide water can not flow into land at rainy and dry season, whereas the remaining are potential land for rice crop. Rice production level at Telang Jaya Village was relatively good with magnitude of 5 tons per hectare. This is in accordance to statement of Alihamsyah et al. (2001) which state that rice production potential at tidal lowland area can achieve 5 tons per hectare by using proper management effort. Input of innovation technology is needed in order to increase rice productivity at tidal lowland area of Telang Jaya Village such as land arrangement, soil tillage, amelioration and balance fertilizing, intensive and 
integrated control for weeds, pests and condition, whereas low rainfall cause the diseases as well as institutional strengthening. decrease of water availability wich

Rainfall is one of climatic factor that affect the occurrence of water table fluctuation. Rainfall which fall on land will enter into soil, resulting in increase of water volume within soil so that it affects water table elevation. Figure 2 showed the highest rainfall was occurred in March with magnitude of 423 $\mathrm{mm} / \mathrm{month}$. The lowest rainfall was occurred in July which is less effective to fulfill crop water requirement. High rainfall cause exessive water on land resulting in flooding subsequently has negative impact on plant's growth. Therefore, effort should be taken to develop optimal water management. Under this climatic condition the areas has enough water to fulfill crop water requirement in the second season (MT1). However maintenance water in the canal is required to reduce water percolation. The water management objective in tidal lowland in type $\mathrm{C}$ was rainfedd water management, due to the tide water could not irrigated the land. (Imanudin et al., 2018a).

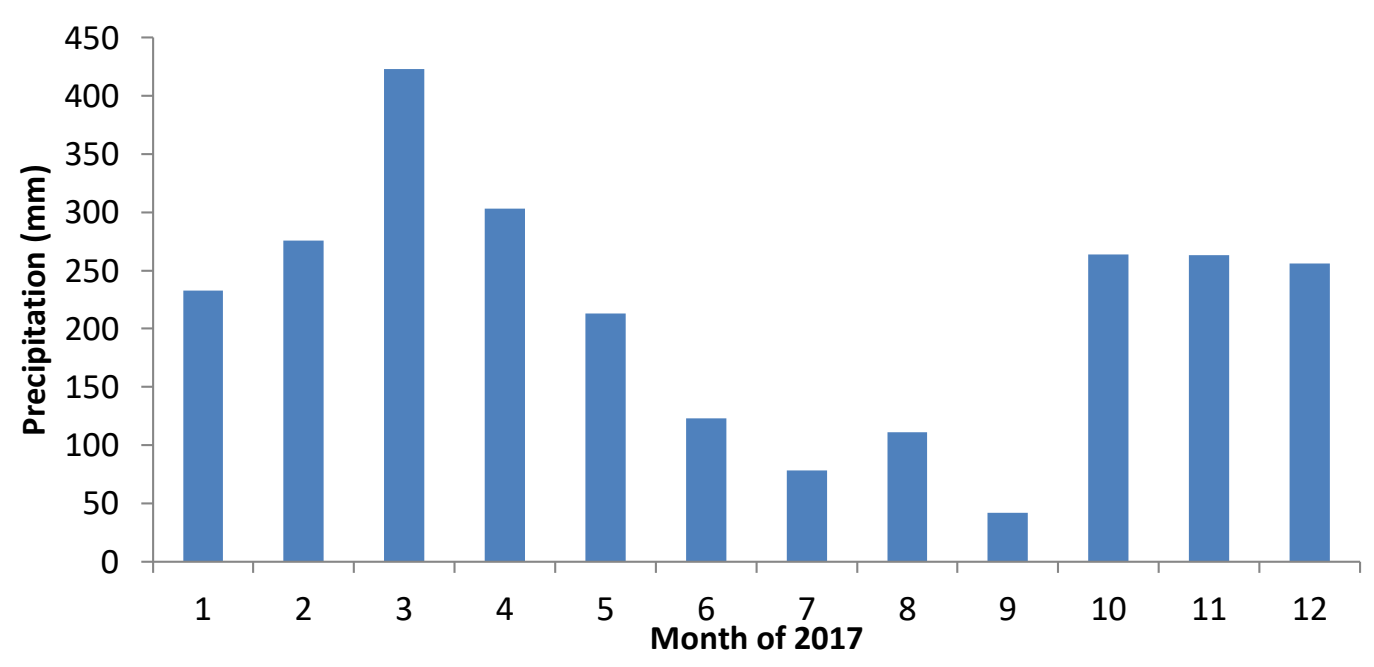

Figure 2. Monthly rainfall in the area study

\section{Soil Properties Evaluation and Improvement}

The observed parameters which determine soil quality and its fertility level at Telang Jaya Village are consisted of soil chemical and physical properties. The soil physical property is soil texture, whereas soil chemical properties are sil $\mathrm{pH}$, Aluminum availability, nutrient contents and organic matter content.

Results of soil textural analysis (Table 1), showed that soil in this location can be classified as clay and clayey loam categories. Clay soil texture is considered as optimal 
texture for crop growth because it has capability to hold water and nutrients, having relatively good movement of water and nutrients, not too sticky and hard so that it has good tillageable, whereas its drainage, aeration and tillage properties are better than that of soil having clay texture.

Table 1. Results of soil texture analysis

\begin{tabular}{ccccl}
\hline \multirow{2}{*}{$\begin{array}{c}\text { Sample } \\
\text { Code }\end{array}$} & \multicolumn{3}{c}{ \% Textural fraction } & \multirow{2}{*}{ Texture } \\
\cline { 2 - 4 } & Clay & Sand & Loam & \\
\hline TS1 & 26.58 & 33.07 & 40.35 & Clay \\
TS2 & 35.44 & 30.23 & 34.33 & Clayey loam \\
TS3 & 30.47 & 33.46 & 36.07 & Clayey loam \\
\hline
\end{tabular}

Research results showed that C-organic content at the study location was cateogorized as high (Table 2). The higher the organic matter content, the more fertile is the soil. Organic matter has a role in determining soil capability to support plants's growth. The roles of organic matter are to increase soil fertility, to improve soil structure, to increase water holding capacity of soil, to increase soil pores and to improve media for soil microbia development (Subekti et al., 2005).

Most of the limiting factor of soil fertility in tidal lowland is acidity. Soil in this location in general can be categorized as very acid with $\mathrm{pH}$ values in the ranges of 4.63 to 4.96 (Table
2). This soil $\mathrm{pH}$ values is still within tolerance limit for the life of microorganisms and vegetations. Low $\mathrm{pH}$ value cause high solubility of $\mathrm{Al}, \mathrm{Fe}$ and $\mathrm{Mn}$ elements which in turn become toxic for plants. On the other hand, if $\mathrm{pH}$ value increase to neutral level or higher followed by rainfall occurrence, the numbers of these ions will decrease within soil solution resulting in lack of $\mathrm{Fe}$ and $\mathrm{Mn}$ elements for certain plants. If $\mathrm{pH}$ value is kept within the range of 6 to 7 , then possibility of $\mathrm{Al}, \mathrm{Fe}$ and $\mathrm{Mn}$ toxicities can be prevented (Hakim et al.,1986). According to Sutandi (2011), the depth of phyrite layer on acid sulphate has effect on soil $\mathrm{pH}$ and $\mathrm{Al}^{\mathrm{dd}}$. The shallower the depth of phyrite layer from soil surface, the lower the soil $\mathrm{pH}$ and $\mathrm{Al}_{\mathrm{dd}}$.

According to (Caires et al., 2008) One of effort to increase soil $\mathrm{pH}$ value is by addition of amelioration substances. The application of amelioration substances in form of dolomite at tidal lowland area has an objective to improve soil chemical and physical characteristics. Some studies had showed that ameliorant addition can increase soil pH (Alvarez et al., 2009; Gomez-Paccard et al., 2013), decrease Al toxicity (Prabagar et al., 2011), Fe (Gonzalo et al., 2013), increase nutrients avalability, improve soil pwater content and soil permeability.

Journal of Wetlands Environmental Management 
Table 2. Analysis results of soil chemical properties at laboratory.

\begin{tabular}{cccccccc}
\hline No & $\begin{array}{c}\text { Sampel } \\
\text { Code }\end{array}$ & $\begin{array}{c}\mathrm{pH} \\
\mathrm{H}_{2} \mathrm{O}^{*}\end{array}$ & $\begin{array}{c}\mathrm{C}- \\
\text { Organic } \\
(\%)^{*}\end{array}$ & $\begin{array}{c}\text { N-total } \\
(\%)^{*}\end{array}$ & $\begin{array}{c}\mathrm{P}- \\
\text { available } \\
(\mathrm{ppm})^{*}\end{array}$ & $\begin{array}{c}\mathrm{K}- \\
\text { exchangeable } \\
(\mathrm{Cmol} / \mathrm{kg})^{*}\end{array}$ & $\begin{array}{c}\text { Al- } \\
\text { exchangeable } \\
(\mathrm{Cmol} / \mathrm{kg})^{*}\end{array}$ \\
\hline 1 & $\mathrm{TS} 1$ & $4.63^{\mathrm{R}}$ & $5.25^{\mathrm{T}}$ & $0.24^{\mathrm{SR}}$ & $9.90^{\mathrm{SR}}$ & $0.38^{\mathrm{S}}$ & 4.12 \\
2 & $\mathrm{TS} 2$ & $4.69^{\mathrm{R}}$ & $6.83^{\mathrm{T}}$ & $0.38^{\mathrm{SR}}$ & $19.65^{\mathrm{S}}$ & $0.38^{\mathrm{S}}$ & 4.68 \\
3 & $\mathrm{TS} 3$ & $4.96^{\mathrm{R}}$ & $2.78^{\mathrm{S}}$ & $0.18^{\mathrm{SR}}$ & $11.10^{\mathrm{R}}$ & $0.51^{\mathrm{S}}$ & 2.52 \\
\hline \multicolumn{7}{l}{ (Based on criteria of CSR/FAO, 1983) SR = Very Low, R = Low, S = Medium, T = High, ST = Very High }
\end{tabular}

Nitrogen is naturally origin from weathered organic matter. Nitrogen has mobile characteristics which means it is easily loss or dissolve as well as evaporate into air. Nitrogen content at the study site is classifies as very low with magnitude of 0.18 to $40 \%$ (Table 2). Low water table elevation causes more aerobe condition of soil which in turn increase decomposition rate and decrease nitrogen losses level due to leaching. Nitrogen in flooded soil usually has the form of $\mathrm{NH}_{4}$ which is relatively easier to loss due to leaching. The desomposition process will be more intensive at better aeration condition (Breeman and Buurman, 2002) such as condition of water table elevation drawdown (Straktova et al., 2011). According to Banach et al.(2009) and Sapek et al. (2009), the increase of $\mathrm{N}$ content in soil was due to water table elevation drawdown. $\mathrm{N}$ can be lost because it flows with water table at flooding condition or water-saturated soil layer condition. This is in accordance to the statement from Reddy and De Laune (2008) which state that one of factor affecting decomposition rate is the increase of soil $\mathrm{pH}$.

Journal of Wetlands Environmental Management Vol 8, No 2 (2020) 85 - 99 http://dx.doi.org/10.20527/jwem.v8i2.228
Soil phosphate content at the study location is classified as very low to medium levels (Table 2). Low phophate content is due to the source of this element is originate from weathering of P-containing mineral. Soils at the study location had low phosphate content with magnitude of about $9.99 \mathrm{mg} \cdot \mathrm{kg}^{-1}$. This is in accordance to statement from Driessen(1978) which showed that available P-content on uncultivated land is usually low because of no input addition and lack of nutrients on swamp land. It is recommended to apply manure fertilizer which have high phophate content such as manure from bird droppings. However, inorganic fertilizers can also be applied such as SP36.

The exchangeable $\mathrm{K}$ content at the study location is classified as medium category with magnitude of about $0.38 \mathrm{Cmol}_{\mathrm{kg}}{ }^{-1}$ (Table 2). Availability level of K-dd is highly affected by $\mathrm{pH}$ and base saturation. Potassium(K) is easily lost and leached at low $\mathrm{pH}$ and low base saturaion, whereas at neutral $\mathrm{pH}$ condition and high base saturation it is fixed by $\mathrm{Ca}$.

The exchangeable $\mathrm{Al}$ (Exch.Al) content at the study location is in the range of 2.52 to 4.68 Cmol. $\mathrm{kg}^{-1}$. According to Yang (2006), 
the presence of pyrite compounds in tidal lowland which are inundated will form ferry hydroxide compounds, sulfate and hydrogen ions thus causing the soil become very acid. It has the solubility $\mathrm{Fe}^{2+}$ and $\mathrm{Al}^{3+}$ increased. (Gergichevich et al., 2010). According to Tisdale et al. (1990), low content of $\mathrm{Al}^{3+}$ and $\mathrm{Fe}^{2+}$, at tidal lowland results in low fertilizing efficiency of phosphate at this area.

Table 2 indicated that the soil fertility at the study location can be categorized as low to medium (Based on criteria of CSR/FAO, 1983). Information of this soil fertility can be used as one of the recommended management for soil properies which determine soil fertility such as soil bases content, available $\mathrm{P}$ and available K. The limiting factors found in this study were $\mathrm{N}$ content of land, soil bases Faktor and soil C-organic.

Efforts that can be done for soil fertility improvement are balance fertilizing management according to crop's requirement, organic matter addition (manure fertilizer, green fertilizer or legume planting) at soil tillage stage in order to maintain good and sustainable soil fertility, management of soil $\mathrm{pH}$ which is suitable for elements or nutrients availability through liming (increasing $\mathrm{pH}$ ) and proper management for irrigation water. Reported by Imanudin et al., (2017) in the condition of the groundwater table in the lower zone of the root $(20-30 \mathrm{~cm})$, the nutrient of the soil is in optimal conditions. On the other hand if the groundwater level is in the sulfide layer the soil quality decreases due to the high iron solubility of aluminum. The increase of aluminum in the soil has the effect of increasing phosphorus bonds and other nutrients. Therefore the fertility status in the soil decreases, and that is a common occurrence in tidal lowland areas.

\section{Ground water table analysis and Shortage (SEW-20)}

In order to determine how far land receive water excess from the system, then analysis of cummulative daily water table toward plant's tolerance limit to water table elevation was implemented. Figure 3 showed that water table elevation was more dominance above $-20 \mathrm{~cm}$, which indicate water condition was in safe zone for rice crop growth. Water had exceeded the critical limit up to $-50 \mathrm{~cm}$ in April up to the middle of May. This condition showed that water management option in this period is water retention. Imanudin and Susanto (2007) had stated that water table elevation at tertiary block can be controlled through water surface regulation in tertiary channel. Subsequently, strategy for management of resources and environment at tidal lowland area which is stressed on development of farm enterprises system and phyrite layer control is developed through the technique of water table elevation control. Control drainage in $50 \mathrm{~cm}$ of water table level in tertiary canal could made ground water table in above sulphidic layer (Imanudin et al., 2018b). 


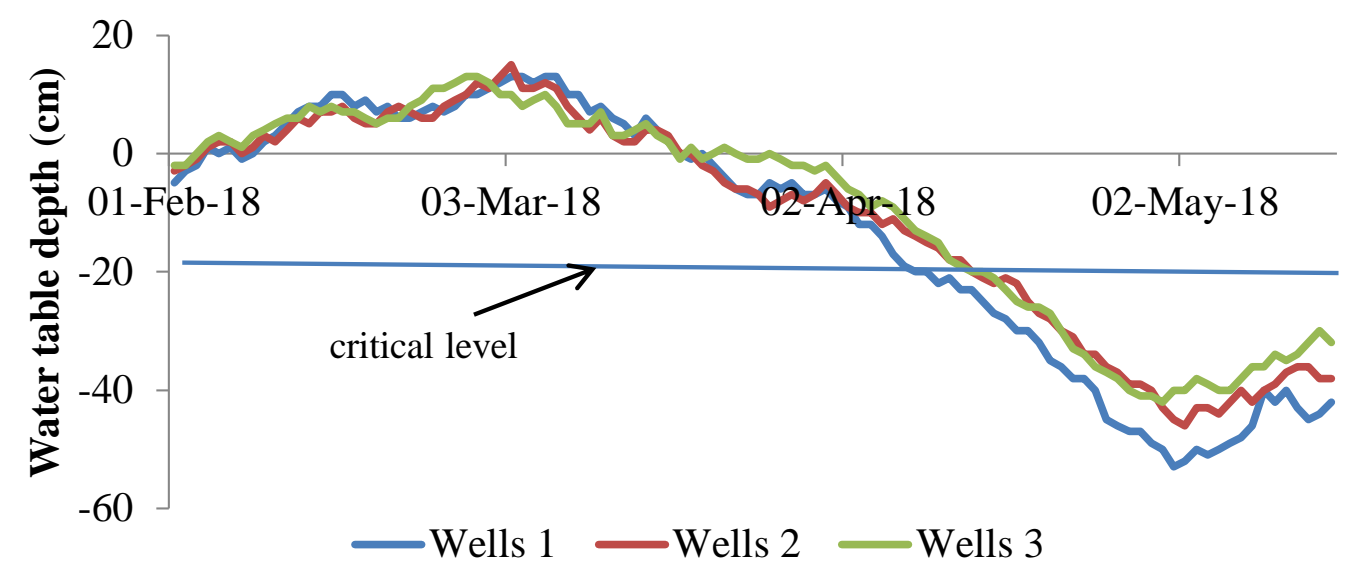

Figure 3. Water table fluctuation in term of critical water level (SEW-20)

Analysis results of daily water table elevation (Figure 2) showed that the lowest water table elevation was occurred in April up to $-50 \mathrm{~cm}$ depth. According to Imanudin et al. (2002), phyrite layer oxidation will occur if water table drop below 1 meter depth. Therefore, scheduling of planting time is the main key to prevent this phyrite layer oxidation. The increase or decrease of water surface in tertiary channel will result in increase or decrease of water table elevation on land with similar magnitude (Imanuddin, 2002). This condition shows that water network can be function as irrigation and drainage for land. The lower location will receive higher water flooding from high seawater tidal than that of higher elevation land location. Water surface in secondary channel will be higher than that of tertiary channel during period of high seawater tidal so that water will enter freely into tertiary channel or into land area. On the contrary, water surface in tertiary channel or land is higher than that of secondary channel during period of low seawater tidal causing water can not flow outward so that water will be retained on land.

Water retention system can be used to prevent water table elevation drawdown (Ngudiantoro, 2010). Water retention is implemented to maintain water table elevation at specific depth. In addition, water retention is also needed to prevent water shortage and to create an environment condition for nutrients absorbtion required by plants. It can be done by closing water gates in tertiary channel during low tidal period and opening the water gates during high tidal period. The optimal condition for the growth and development of rice plant is that water is not in excess or in shortage condition which depend on each growing phase of rice plant. In addition, water gates operation in tertiary channel has important role on irrigation and drainage at farm enterprise land.

In land type $\mathrm{C}$ the crop water requirement was strongly affected by capillary rise. Reported by Fan-Yang (2011) under loamy 
soil daily capillary rise is higher under shallower groundwater table. When the groundwater table is under $1.0 \mathrm{~m}$, then the water supply by capillary rise ranged from 0 to $1.12 \mathrm{~mm}$ day-1. Since the water table under $1.4 \mathrm{~m}$ the capillary water ranged from 0 to $0.86 \mathrm{~mm}$ day-1. Thus the crop water requirement is still need irrigation water, when the water table is lower than $1,0 \mathrm{~m}$. Added by Ali et al. (2013) that model simulation using UPFLOW showed that the moisture condition in the root zone is saturated when the ground water table in the $0.2 \mathrm{~m}$. The maximum capillary rise is $2.4 \mathrm{~mm}$ day-1 when the ground water table at $0.65 \mathrm{~m}$. Also reported by Hua et al (2017) the experimental research showed that the soil moisture condition at depths between $10 \mathrm{~cm}$ to $20 \mathrm{~cm}$ were strongly affected by rainfall or irrigation water than contribution by capillary rise. While in depth lower than $40 \mathrm{~cm}$, the soil moisture was significantly contributed by vertical water movement (capillary rise).

Rice plant requires water depth located between $-20 \mathrm{~cm}$ up to $-30 \mathrm{~cm}$ below soil surface. If water table located below $-20 \mathrm{~cm}$, then rice plant will experience water shortage which subsequently cause water stress so that irrigation water should be applied on farm enterprise land. Reported by Mishra et al. (1990) the ground water table in $(<30 \mathrm{~cm})$ for most part of the rice growing stage, could have the optimum yield (55-60 q ha ${ }^{-1}$ ). However the water table elevation at $20 \mathrm{~cm}$ up to $30 \mathrm{~cm}$ below soil surface was also need intermittent irrigation to have maximum yield. In this case the rainfall still occurs during February to May period. Therefore the environmental condition for rice growth was suitable like in the irrigation rice system. Reported by Husain et al. (2009) that the alternative wet and dry (irrigation applied every three days) was not significant effect with the rice production under continues flooding. By this irrigation system rice production was about $7-8$ ton/ha. However the intermittent system was able to save water between $25-30 \%$. Therefore the contribution of water by capillary rice (shallow ground water table) in combination with rainfall was successfully meet water requirement for rice cultivation during March to May (second crop of rice).

\section{On Farm Water Management}

Suscessfulyy agrictulture in tidal lowland is depend on the parmer can control the water table in tertiary block (farm level) to crop support water requirement. Water management at the study location affected by swamp condition is related to suitability between quantity and frequency of available water. Water availability is affected by local climate factor existing at the study location , especially rainfall. Therefore the water management objective is mainly to retain water. Espesialy in the period of February to May (MT2).

One of the most dominant climatic element is rainfall because it is directly affect the availability of water resource. In addition, air temperature, air relative humidity and solar radiation are also climatic elements which determine land productivity. Rainfall data

Journal of Wetlands Environmental Management 
consisting of rainfall magnitude and its distribution is frequently used to predict water availability potential for agriculture.

The effect of seawater tidal is more dominant than that of rainfall. The study site is located at C-floding type land where high and low seawater tidal only have effect on water surface in channel. Land and water management as well as cultivation technology to be applied on tidal lowland area should be adapted to land typhology and water flooding type. According to Imanudin et al. (2011), water management option is the basic consideration which is subsequently elaborated into operational guideline for the existing water structures. Water table elevation control at tidal lowland area is a key process that should be properly implemented through water management at macro and micro levels.
Water status availability in the period of February to March is sufficient for rice growth (Figure 4). The water table was $5-10 \mathrm{~cm}$ above soil surface (flood). It is indicated that on vegetative period the water availability for rice was suffincient. However starting on April the water table drop to $-5-10 \mathrm{~cm}$ below surface. Actualy in that period rice growth was entered in generative stage, that need water table in level at $0 \mathrm{~cm}$ minimum. Then the water management objective should have suplay water from out site. Pumping irrigation is one the best option to delivery water form tertiary canal to teriatiry block during the high tide. However under normal climatic condition the pumping irrigation does not required. Rainfall water was sufficien enough to increase the water table close to the soil surface. Pumping irrigation in the field was required when no rainfall during one week.

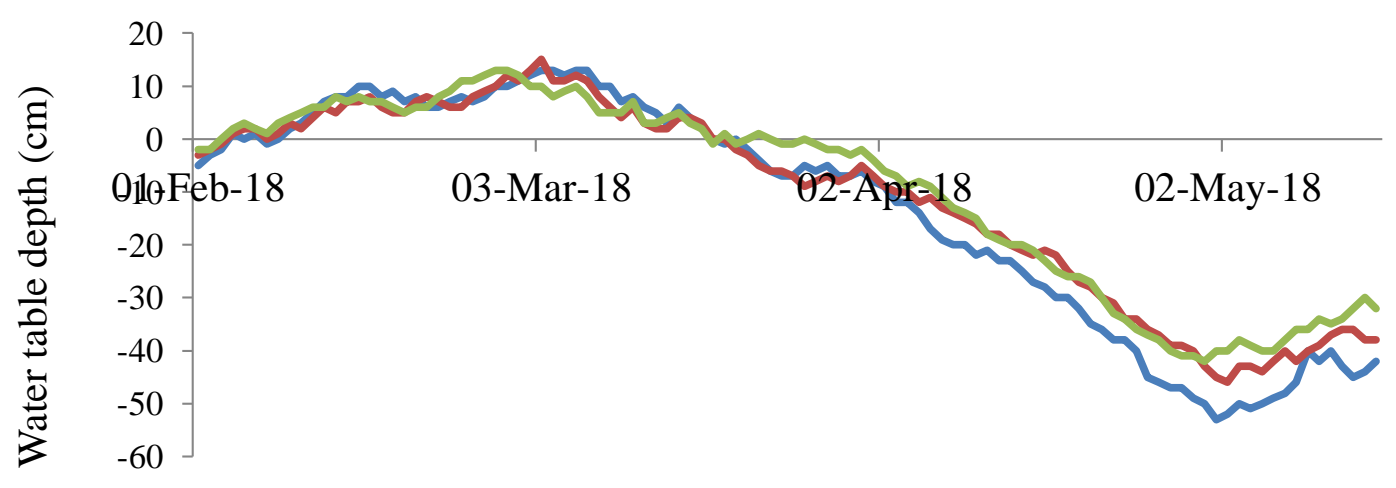

Wells $1 \longrightarrow$ Wells $2 \longrightarrow$ Wells 3

Figure 4. Water table fluctuation on tertiary block during MT2 of rice (1 February - 15 May 2018) 


\section{Relationship Between Water Management and Rice Production}

Water management at tidal lowland area is basically an effort to manage or regulate water excess according to water requirement of cultivated pants. Water management at tidal lowland area is not only to deliver water into land and to drain water out of land so that water is available for crops, but also to leach the residual toxic elements available on land. According to Imanudin et al.( 2010; 2011), soil $\mathrm{pH}$ is very low during dry season period. However, water table elevation progressively increase at initial period of rainy season (MT1) which results in increase of soil $\mathrm{pH}$. Condition of water table status relative to phyrite layer position is the key factor for water and land management for each swamp development unit. Table 3 is the model operation for maintenance the water table in tertiary block under various developing stage of rice. To develop model operated (Table 3), farmers was recorded the water gate daily. It was based on the crop water requirement in tertiary block. In second season rainfall was sufficient to fulfill crop evapotranspiration. It was achieved when the tertiary canal is full of water than zero percolation. This also reported by Bakri et al. (2014) water management option in dry areas (rainfed rice) was mainly focus on retained water. Rainfall water as much as possible to harvest rain water. Then gate in tertiary canal was fully closed to have as much as possible rain water.
Tabel 3. The field work operation on tertiary canal for maintance water table

\begin{tabular}{lll}
\hline $\begin{array}{l}\text { Development } \\
\text { stage }\end{array}$ & \multicolumn{2}{c}{$\begin{array}{c}\text { Tertiary canal operation } \\
\text { under diferent climatic } \\
\text { conditions }\end{array}$} \\
\cline { 2 - 3 } & \multicolumn{2}{c}{$\begin{array}{l}\text { Normal } \\
\text { and wet } \\
\text { condition }\end{array}$} \\
\hline Initial growth & Control & Retaining water \\
& drainage & \\
\hline Vegetative & Retain & Retaining \\
growth & water & water/supply \\
\hline Genarative & Retain & Suplay \\
growth & water & water/pumping \\
\hline Ripenning & Drainage & Control \\
& & drainage \\
\hline
\end{tabular}

Under high land topography (type C) water suplay can only be done by using pumping irrigation. During the high tide the water from secondary canal was delivered to tertiary canal. After 2-3 hour tide water entering tertiary canal, than the pumping irrigation operated in order to pulfill water in tertiary block (farm). Pumping with outlet of 8 inc in diameter was operated within 2 hours to irrigated one hectare land (Figure 5). During the elnina climatic condition pubp was operated 5 times to pump water from tertiary canal to rice field. However, highland topography was beteer to use rainfed rice technique, where the rice has tolereant to drought (Ohno et al., 2019). Experimental plot in three locations in northern Luzon, of Philippines was get rice production 3-3.5 ton/ha using this technique.

Journal of Wetlands Environmental Management

Vol 8, No 2 (2020) 85 - 99

http://dx.doi.org/10.20527/jwem.v8i2.228 

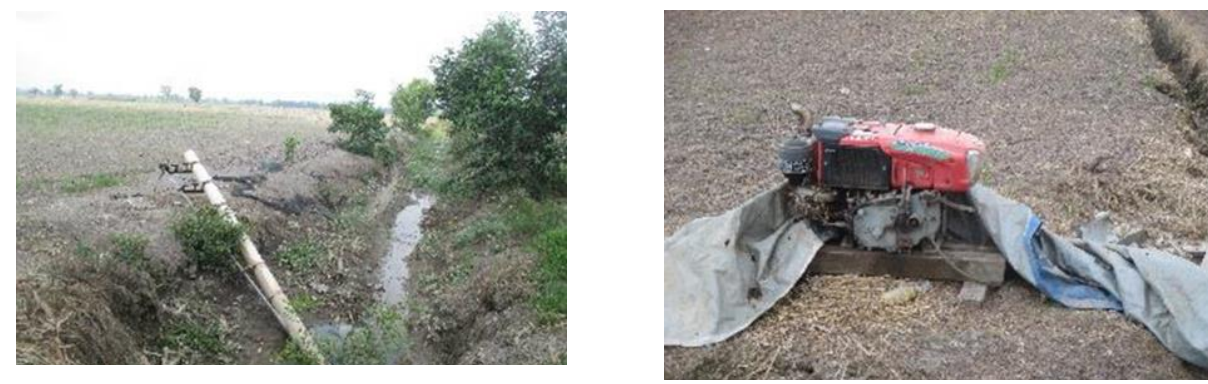

Figure 5. Pumping irrigation insturment during rice cultivation.

Water management can maintain water table elevation on land plot and improper water management affect the decrease of crop production. Rice plant can properly grow and develop if water table elevation on land is also maintained. This is in accordance to study results by Imanudin dan Bakri (2014) which showed significant relationship between the decrease of crop production and water table availability. The study of Fahmi et al. (2004) showed that the increase of rice production through organic fertilizer addition was due to improvement of soil chemical properties such as the increase of $\mathrm{pH}$ and decrease of $\mathrm{Fe}^{2+}$ concentration. Phosphate addition had cause the increase of rice tonnage. Subiksa and Diah (1992) had stated that phosphate fertilizer has slow release characteristics (it release $\mathrm{P}$ in progressive manner) so that it is more effective on acid sulphate soils.

\section{CONCLUSION}

1. Soil fertility status at Telang Jaya Village generally is low up to medium so that it requires better land management through nutrients addition in form of fertilizers.

2. Water management objective for rice in the second crop was for control drainage during the initial stage, and retained the rain water during vegetative stage. During el-nina climatic condition, the pumping irrigation is required at generative phase.

3. Land utilization in effort for agricultural development has relatively high opportunity because consisting of several ecosystems affected by seawater tidal movement and variable salinities as well as seawater which contains different elements either originate from the bottom of the sea itself or from mainland.

\section{REFERENCES}

Ali , M.H., Abustan, I., Islam, S. 2013. Simulation of upward flux from shallow water-table using UPFLOW model. Journal of Natural Resources and Development 03: 123-127.

Alihamsyah, T., E. Ananto H. Supriadi, I.G. Ismail, and D.E. Sianturi. 2000. Fourteen Years Research on Swamp Land: Supporting Future Agrciluture. Research 
and Development Project on Integrated Seamp Agriculture - ISDP. Agricultural Research and Development Council. Bogor.

Alihamsyah, T., D. Nazemi, Mukhlis, I. Khairullah, H.D. Noor, M. Sarwani, H. Sutikno Y. Rina, F.N. Saleh, dan S. Abdussamad.2001. Fourt Years of Balitra: Future Reserach and Deveopment. Research Council of Food and Horticultural Crops. Jakarta.

Bakri, Bernas M., and Imanudin, M.S. 2015. Water Retention option of drainage system for dry season corn cultivation at tidal lowland area. International Journal AGRIVITA 37 (3) 237-246.

Banach AM, K Banach, EJW Visser, Z. Stepniewska, AJM Smits, JGM Roelofs and LPM Lamers. 2009. Effects of summer flooding on flood plain biogeochemistry in Poland; implications for increased flooding frequency. Biogeochemistry 92, 247-262.

Breemen, N.V and P., Buurman. 2002. Soil Formation, $2^{\text {nd }}$ edition, 404. Kluwer Academic Publisher. Dordrecht, USA.

Cairns, D. (2008). Essential of Pharmaceutical Chemistry. Third edition. London : Pharmaceutical Press. Pages 177-180.

Driessen, P.M. and R., Dudal. 1991. The Major Soils of the World. Wageningen Agricultural University.

Fan Yang, Guangxin. Z., Xiongrui. Y., Zhijun, L., Zhigang, H. 2011. Study on capillary rise from shallow groundwater and critical water table depth of a salinesodic soil in western Songnen plain of China. Environ Earth Science. 64:21192126

Fahmi, A., Susilawati, A., and Jumberi, A., 2004. The Dynamics of Iron, Sulphate, Posphorous and Rice Yield due to Soil
Tillage, Micro Channel and oRganic Fertilizer Land. Journal of Tropical Soils. 14: 119-125

Gergichevich, C.M., Alberdi, M., Ivanov, A.G. and Diaz, M.R. 2010. $\mathrm{Al}_{3}{ }^{+}-\mathrm{Ca}_{2}{ }^{+}$ Interaction in plants growing in acid soils: Al-phytotoxicity response to calcareous amandements. Journal of Soil. Science and Plant Nutrition 10 (3): 217-243.

Hua, W., Chuanhai, W., Gang, C., Hai Y., Zhai, Y. 2017. Measurement and Simulation of Soil Water Contents in an Experimental Field in Delta Plain. Water 2017, 9, 947; doi:10.3390/w9120947

Hartoyo, S., Erwin R., Sumarjo G,I., Robiyanto, H.S., Baart, S.Surjadi, F.X, Ad Van Den Eelart. 2010. Land and water management of tidal lowlands: Experiences in Telang and Saleh, South Sumatra. Irrigatian and Drainage. 59(3): 317-335

Hakim, N. M. Y. Nyakpa., A. M. Lubis., S. G. Nugroho., M. R. Saul., M. Diha., G. B. Hong., dan H. H. Bailey. 1986. Principles of Soil Science. Lampung University. Lampung.

Imanudin, M.S. M. Edi Armanto,Bakri.2019. Determination of Planting Time of Watermelon Under a Shallow Groundwater Table in Tidal Lowland Agriculture Areas of South Sumatra, Indonesia. Irrigation and Drainage Journal 68(3). 488-495

https://doi.org/10.1002/ird.2338

Imanudin, M.S., Bakri , Armanto, E., Indra, B2 and Ratmini, S.N.P. 2018 a. Land And Water Management Option of Tidal Lowland Reclamation Area to Support Rice Production (A Case Study in Delta Sugihan Kanan of South Sumatra Indonesia). Journal of Wetlands Environmental Management 6 (2): p. 93111. 
Imanudin.M.S., Elisa W., Edi Armanto, M. 2018b. Option for land and water management to prevent fire in peat land areas of Sumatera Indonesia. Journal of Wetlands Environmental Management. 6 (1): p. 12-26.

Imanudin MS, Armanto ME, Susanto RH. 2011. Developing seasonal operation for water table management in tidal lowland reclamation at South Sumatera Indonesia. Journal of Tropical Soils. Lampung Univerisity.16(3): 233-244

Mishra, H.S. Rathore, T.R., Pant, R.C. 1990. Effect of intermittent irrigation on groundwater table contribution, irrigation requirement and yield of rice in Mollisols of the Tarai region Agricultural Water Management. 18 (3): 231-241.

Ngudiantoro. 2010. Water table fluctuations model in tidal Lowland C/D type. A case Study in South Sumatera. Science Research Journal 13(3): 12-18.

Ohno, H. Niño, P.M.C. Banayo., Crisanta, Bueno, Jun-ichi, Kashiwagi, Taiken
Nakashima, KazutoIwama, Aurora, M.Corales, Ricardo Garcia, Yoichiro Kato. 2019. On-farm assessment of a new early-maturing drought-tolerant rice cultivar for dry direct seeding in rainfed lowlands. Field Crops Research.219. 222-228

Proyek Irigasi dan Rawa Andalan (PIRA). 2004. Lowland Development Information Data at South Sumatera.

Schultz B, Susanto RH, Suryadi FX, Waskito AS. 2015. Analysis of water management inreclaimed tidal lowlands of Indonesia. Experiences in the Telang I Scheme, Musi Delta, South Sumatra. In Kop J, Ravensteijn W, Kop K (eds). Irrigation Revisited. An Anthology of IndonesianDutch Cooperation 1965-2014. Eburon: Delft, the Netherlands/Jakarta, Indonesia.

Subiksa IGM. and Diah, S. 1992. Natural Phosphate Utilization for Acid Sulphate Land. 